\title{
Brucellosis and Associated Risk Factors Analysis in Serum Sample of Bovines
}

\author{
Raghavendra Prasad Mishra ${ }^{1} *$, Udit Jain ${ }^{1}$, Kaushal Kusum², \\ Parul Singh ${ }^{1}$, Barkha Sharma ${ }^{3}$ and Gourab Basak ${ }^{1}$
}

\begin{abstract}
${ }^{1}$ Department of Veterinary Public Health, ${ }^{3}$ Department of Veterinary Epidemiology and Preventive Medicine, College of Veterinary Sciences and Animal Husbandry, Pandit Deen Dayal Upadhayay Pashu Chikitsa Vigyan Vishvidhyalaya Ewam Go-Anusandhan Sansthan (DUVASU), Mathura, 281001, Uttar Pradesh, India

${ }^{2}$ Department of Veterinary Gynaecology\& Obstetrics, Apollo College of Veterinary Medicine, Rajasthan University of Veterinary \& Animal Sciences, (RAJUVAS), Jaipur, 302031, Rajasthan India
\end{abstract}

*Corresponding author

\section{A B S T R A C T}

\section{Keywords}

Bovine Serum, RBPT, STAT, IELISA

\section{Article Info}

\section{Accepted:}

17 June 2020 Available Online: 10 July 2020
A total of 567 bovine serum samples were taken from four districts of Brij region of U.P.All the samples were processed to detection of prevalence of brucellosis by RBPT, STAT and ELISA. Out of 567 bovine serum sample, the prevalence of brucellosis in 391 cattle were found to be $07.93 \%$ (31/391), 08.69\% (34/391) and 10.74\% (42/391) shows positive by RBPT, STAT and I- ELISA respectively and 176 buffaloes tested serum sample the seroprevalence were found to be $09.66 \%$ (17/176), $10.79 \%(19 / 176)$ and $12.5 \%$ (22/176) positive by RBPT, STAT and I- ELISA respectively. The seroprevalence of brucellosis to this region may have public health significance. It is recommended that good management and hygienic practices shall be performed during handling of cattle and buffaloes.

\section{Introduction}

Brucellosis is one of the world's major zoonotic problems. Brucellosis is caused by members of genus Brucella. These are small, non-motile, aerobic, facultative intracellular, Gram-negative coccobacilli. The ability of
Brucella to replicate and persist in host cells is directly associated with its capacity to cause persistent disease and to circumvent innate and adaptive immunity (Fichi, 2003). The species of Brucella and their major hosts are Br. abortus (cattle), Br. melitensis (goats), Br. suis (swine) and Br. ovis (sheep). 
Br.abortus also causes infection in horses and is commonly found in chronic bursal enlargements as a secondary invader rather than a primary pathogen (Radostits et al., 2000). Brucellosis is a zoonotic disease that exists worldwide and is more or less endemic in most African countries and still exists in some southern European countries (Refai, 2002). Brucellosis is transmitted from mother to offspring before or at the birth, through milk, by sexual contact, direct physical contact, from polluted environments and from eating spoiled raw meat mainly placenta and birth products. Brucellosis is clinically characterized by metritis, mastitis, repeat breeding, abortion in the last trimester of pregnancy, retention of placenta and reduced milk production in the female whereas epididymitis, orchitis and sterility in male (Sundar et al., 2015). Human infected with Brucella may suffer from a debilitating nonspecific illness which involves in of various organs. Some agents identified recently in human brucellosis include $B$. neotomae which was previously thought not to be zoonotic, and the novel organism $B$. inopinata. brucellosis is considered to be an occupational disease that mainly affects slaughter house workers, butchers and veterinarians. Symptoms in human brucellosis can be highly variable, ranging from nonspecific, flu-like symptoms to undulant fever, arthritis, orchitis and epididymitis (Hassan et al., 2012). Brucella abortus, is an important zoonotic disease which leading to several public health and economic problems in all over the world. The prevalence of brucellosis in India was first established early in the previous century and since then it has been reported from almost all the states (Sehgal and Bhatia, 1990; Renukaradhya et $a l .$, 2002). It is a highly infectious zoonotic disease, with a great economic impact on cattle farming with the estimated loss of US\$ 58.8 million per year in India (Kollannur et al., 2007).

\section{Materials and Methods}

\section{Sources and places of sample collection}

The present study was conducted in four districts viz., Mathura, Agra, Hathras and Kasganjf rom august, 2017 to march, 2019. These districts were selected because of the high numbers of smallholder dairy farmers, gaushalas and good animal husbandry practices. During the present study, about 10 $\mathrm{ml}$ of blood from each animal and total 567 samples (391 cattle and 176 buffalo sera sample) were collected in aseptic conditions using labeled sterile disposable syringes (Dispovan) or vaccutainers (BD, USA). Distribution of samples collected from different districts with their associated risk factors viz. species, area and health status. The serum was separated after clotting of blood and transported to laboratory on ice. All the serum samples were stored at $-20^{\circ} \mathrm{C}$ till tested.

\section{Prevalence based on different serological tests}

RBPT \& STAT antigen were procured from Indian Veterinary Research Institute, (IVRI), Izatnagar, India and I-ELISA, kit was procured from Svanova (Biotech-AB), Uppasala, Sweden Briefly, each of the 96 wells of flat bottom polystyrene antigen precoated with Brucella abortus antigen. RBPT antigen is an $8 \%$ suspension of pure smooth killed cells of Brucella abortus strain 99 phenolised and stained with rose bengal dye. Rosebengal plate test is a single dilution serum agglutination test. It was performed on glass slides according to the method presented by Alton et al., (1998). To detection of STAT in a serum samples, Brucella abortus plain antigen were taken which was heat killed phenolised suspension of Brucella abortus strain 99 and it show 50\% agglutination at $1 / 500$ final dilution of serum with Indian standard. 


\section{Results and Discussion}

\section{Species wise seropositivity of bovine} brucellosis

The overall prevalence of bovine brucellosis in serum by different serological test viz. RBPT, STAT and I-ELISA was $08.46 \%$ $(48 / 567), \quad 09.35 \% \quad(53 / 567)$ and $11.28 \%$ (64/567) respectively. Out of 391 tested cattle serum sample, the seroprevalence of brucellosis was found to be $07.93 \%$ (31/391), $08.69 \%$ (34/391) and $10.74 \%$ (42/391) shows positive by RBPT, STAT and I- ELISA respectively. In buffaloes out of 176 tested serum sample the seroprevalence was found to be $09.66 \%$ (17/176), $10.79 \%(19 / 176)$ and $12.5 \%$ (22/176) positive by RBPT, STAT and I- ELISA respectively. Thus the seroprevalence of bovine brucellosis is significant higher in buffaloes as compare to cattles. The seroprevalence of brucellosis was nonsignificantly higher in buffaloes as compare to cattles $(\mathrm{p}=0.541)$. In present study the sero-prevalence of brucellosis in cattle and buffalo by I-ELISA was $10.74 \%$ and $12.5 \%$ respectively in serum samples. Our finding were very close to the reports of (Kebede et al., 2008) (11\%), Eshetu et al., (2005) (10\%) and $9.7 \%$ by Aggad and Boukraa, (2006). Higher prevalence rates were also reported in cattle in Nigeria (32.2\%) (Junaidu et al., 2008), (42.31\%) Berhe et al., (2007), (31.5\%) Aggad and Boukraa, (2006) in Algeria and (25.8\%) Ahmad et al., (2009) in Jordan. Some lower prevalence rate was reported by Kassahun (2004) for intensive (2.5\%) and extensive farms $(1.7 \%)$ in Southern Ethiopia, Algeria Berhe et al., (2007) (3.19\%) in extensive production systems.

\section{Area wise seropositivity of bovine brucellosis}

The overall seroprevalence of bovine brucellosis in serum collected from four districts and tested by different serological test like RBPT, STAT and I-ELISA in bovines was given in (table- 2). On the basis of RBPT district wise seroprevalenve in cattle was higher in Hathras (10.00\%) followed by Agra (08.42\%), Kasganj (07.05) and Mathura $(06.87 \%)$ and in buffalo the highest percentage in Mathura (12.19\%) followed by Hathras (10.90\%) Agra (10.00\%) and Kasganj $(05.00 \%)$. On the basis of STAT district wise seroprevalenve in cattle was higher in Agra $(09.47 \%)$ followed by Mathura (09.16\%), Hathras (08.75\%) and Kasganj (07.05\%) and in buffalo the highest percentage in Agra $(15.00 \%)$ followed by Kasganj (10.00\%), Mathura (09.75\%) and Hathras (09.09 \%). On the basis of I-ELISA district wise seroprevalenve in cattle was higher in Hathras (12.50\%) followed by Agra (11.57\%), Mathura (10.68\%) and Kasganj (8.23\%) and in buffalo the highest percentage in Mathura (19.51\%) followed by Agra (12.50\%), Hathras (10.90\%) and Kasganj (07.50\%).

In all four districts the seroprevalence of bovine brucellosis was not significantly associated. Districts wise prevalence of brucellosis in animals revealed that it was widely prevalent in an all circumstances and showed great affinity to all environments. Previous reports Neha et al., (2015) also somewhat similar to present study. Difference of brucellosis in different districts might be due to climatic conditions, rearing practices, intermixing of different species animal and sharing same pasture land, interaction of wild animal due to deforestation and livestock movement (Matope et al., 2011; OIE, 2011; Manish et al., 2013). In a present study the nonsignificant association between Brucella infection and risk factors such as abortion, metritis, retention of placenta, stillbirth and repeat breeding was reported. Some researchers report was similar to present findings Mugizi et al., (2015) and Asmare et al., (2013) found no significant association between seroprevalence of Brucella in respect of abortion and retention of placenta. 
(Aulakh et al., 2008) found significant association between brucellosis and abortion and retention of placenta, but not between brucellosis and repeat breeding.

Seropositivity of bovine brucellosis according to animal health

According to reproductive diseased animals the seroprevalence of bovine brucellosis on the basis of I-ELISA test was higher in case of abortion in both cattle $21.62 \%$ and buffalo $22.23 \%$. In cattle the lower seroprevalence was found in case of retention of placenta $06.25 \%$ while in case of buffalo no any finding in case of still birth and retention of placenta (table-3).

Table.1 Species wise seropositivity of bovine brucellosis (cattle and buffalo) detected by RBPT, STAT and I-ELISA

\begin{tabular}{|c|c|c|c|c|c|c|c|c|c|}
\hline $\begin{array}{c}\text { S. } \\
\text { No. }\end{array}$ & Species & $\begin{array}{l}\text { No. of } \\
\text { serum } \\
\text { sample }\end{array}$ & $\begin{array}{c}\text { No. of } \\
\text { samples } \\
\text { positive } \\
\text { by } \\
\text { RBPT }\end{array}$ & $\begin{array}{c}\text { Percent } \\
\text { positivity } \\
\text { by } \\
\text { RBPT }\end{array}$ & \begin{tabular}{|l} 
No. of \\
samples \\
positive \\
by \\
STAT
\end{tabular} & $\begin{array}{c}\text { Percent } \\
\text { positivity } \\
\text { by } \\
\text { STAT }\end{array}$ & $\begin{array}{c}\text { No. of } \\
\text { samples } \\
\text { positive } \\
\text { by I- } \\
\text { ELISA }\end{array}$ & $\begin{array}{c}\text { Percent } \\
\text { positivity } \\
\text { by I- } \\
\text { ELISA }\end{array}$ & $\begin{array}{c}p \\
\text { value }\end{array}$ \\
\hline 1 & Cattle & 391 & 31 & 07.93 & 34 & 08.69 & 42 & 10.74 & \multirow[t]{2}{*}{0.541} \\
\hline \multirow[t]{2}{*}{2} & Buffalo & 176 & 17 & 09.66 & 19 & 10.79 & 22 & 12.5 & \\
\hline & Total & 567 & 48 & 08.46 & 53 & 09.35 & 64 & 11.28 & \\
\hline
\end{tabular}

$\mathrm{p}>0.05$ at $5 \%$ level of significance

Table.2 Area wise seropositivity of bovine brucellosis (cattle and buffalo) in serum samples detected by RBPT, STAT and I-ELISA

\begin{tabular}{|c|l|l|l|c|c|c|c|c|c|c|}
\hline $\begin{array}{c}\text { S. } \\
\text { No }\end{array}$ & $\begin{array}{l}\text { Name of } \\
\text { District }\end{array}$ & Source & $\begin{array}{c}\text { No. of } \\
\text { serum } \\
\text { sample }\end{array}$ & $\begin{array}{c}\text { No. of } \\
\text { samples } \\
\text { positive } \\
\text { by RBPT }\end{array}$ & $\begin{array}{c}\text { Percent } \\
\text { positivit } \\
\text { y by } \\
\text { RBPT }\end{array}$ & $\begin{array}{c}\text { No. of } \\
\text { samples } \\
\text { positive } \\
\text { by } \\
\text { STAT }\end{array}$ & $\begin{array}{c}\text { Percen } \\
\text { t } \\
\text { positiv } \\
\text { ity by } \\
\text { STAT }\end{array}$ & $\begin{array}{c}\text { No. of } \\
\text { samples } \\
\text { positive } \\
\text { by I- } \\
\text { ELISA }\end{array}$ & $\begin{array}{c}\text { Percent } \\
\text { positivi } \\
\text { ty by I- } \\
\text { ELISA }\end{array}$ & $\begin{array}{c}\text { p } \\
\text { value }\end{array}$ \\
\hline $\mathbf{1}$ & Mathura & Cattle & 131 & 9 & 06.87 & 12 & 09.16 & 14 & 10.68 & 0.139 \\
\hline & & Buffalo & 41 & 5 & 12.19 & 4 & 09.75 & 8 & 19.51 \\
\hline $\mathbf{2}$ & Agra & Cattle & 95 & 8 & 08.42 & 9 & 09.47 & 11 & 11.57 & 0.877 \\
\hline & & Buffalo & 40 & 4 & 10.00 & 6 & 15.00 & 5 & 12.50 & \\
\hline $\mathbf{3}$ & Hathras & Cattle & 80 & 8 & 10.00 & 7 & 08.75 & 10 & 12.50 & 0.778 \\
\hline & & Buffalo & 55 & 6 & 10.90 & 5 & 09.09 & 6 & 10.90 & \\
\hline $\mathbf{4}$ & Kasganj & Cattle & 85 & 6 & 07.05 & 6 & 07.05 & 7 & 08.23 & 0.249 \\
\hline & & Buffalo & 40 & 2 & 05.00 & 4 & 10.00 & 3 & 07.50 \\
\hline
\end{tabular}

$\mathrm{p}>0.05$ at $5 \%$ level of significance 
Table.3 Seropositivity of bovine brucellosis according to animal health

\begin{tabular}{|c|c|c|c|c|c|c|c|c|c|c|}
\hline $\begin{array}{l}\text { S. } \\
\text { No. }\end{array}$ & $\begin{array}{l}\text { Disease } \\
\text { condition }\end{array}$ & Source & $\begin{array}{l}\text { No. of } \\
\text { serum } \\
\text { sample }\end{array}$ & $\begin{array}{c}\text { No. of } \\
\text { samples } \\
\text { positive } \\
\text { by RBPT }\end{array}$ & $\begin{array}{c}\text { Percent } \\
\text { positivity } \\
\text { by RBPT }\end{array}$ & $\begin{array}{c}\text { No. of } \\
\text { samples } \\
\text { positive } \\
\text { by STAT }\end{array}$ & $\begin{array}{c}\text { Percent } \\
\text { positivity } \\
\text { by STAT }\end{array}$ & $\begin{array}{c}\text { No. of } \\
\text { samples } \\
\text { positive } \\
\text { by I- } \\
\text { ELISA }\end{array}$ & $\begin{array}{c}\text { Percent } \\
\text { positivity } \\
\text { by I- } \\
\text { ELISA }\end{array}$ & p value \\
\hline \multirow[t]{2}{*}{1} & \multirow[t]{2}{*}{ Abortion } & Cattle & 37 & 6 & 16.21 & 7 & 18.91 & 8 & 21.62 & \multirow[t]{2}{*}{0.967} \\
\hline & & Buffalo & 18 & 3 & 16.67 & 3 & 16.67 & 4 & 22.23 & \\
\hline \multirow[t]{2}{*}{2} & \multirow[t]{2}{*}{ Still birth } & Cattle & 12 & 1 & 08.34 & 1 & 08.34 & 1 & 08.34 & \multirow[t]{2}{*}{0.394} \\
\hline & & Buffalo & 9 & 0 & 0 & 0 & 0 & 0 & 0 & \\
\hline \multirow[t]{2}{*}{3} & \multirow[t]{2}{*}{ Payometra } & Cattle & 24 & 2 & 08.34 & 1 & 04.16 & 2 & 08.34 & \multirow[t]{2}{*}{0.698} \\
\hline & & Buffalo & 16 & 1 & 06.25 & 2 & 12.50 & 2 & 12.50 & \\
\hline \multirow[t]{2}{*}{4} & \multirow[t]{2}{*}{ Metritis } & Cattle & 15 & 1 & 06.67 & 2 & 13.34 & 1 & 06.67 & \multirow[t]{2}{*}{0.832} \\
\hline & & Buffalo & 11 & 1 & 09.09 & 0 & 0 & 1 & 09.09 & \\
\hline \multirow[t]{2}{*}{5} & \multirow{2}{*}{$\begin{array}{l}\text { Retention of } \\
\text { placenta }\end{array}$} & Cattle & 16 & 1 & 06.25 & 0 & 0 & 1 & 06.25 & \multirow[t]{2}{*}{0.512} \\
\hline & & Buffalo & 7 & 0 & 0 & 0 & 0 & 0 & 0 & \\
\hline \multirow[t]{2}{*}{6} & \multirow{2}{*}{$\begin{array}{l}\text { Repeat } \\
\text { breeding }\end{array}$} & Cattle & 76 & 8 & 10.52 & 10 & 13.15 & 12 & 15.78 & \multirow[t]{2}{*}{0.630} \\
\hline & & Buffalo & 34 & 4 & 11.76 & 5 & 14.70 & 4 & 11.76 & \\
\hline \multirow[t]{3}{*}{7} & \multirow{2}{*}{$\begin{array}{l}\text { Apparently } \\
\text { healthy } \\
\text { (Anoestrus) }\end{array}$} & Cattle & 211 & 12 & 05.68 & 13 & 06.16 & 17 & 08.05 & \multirow[t]{2}{*}{0.197} \\
\hline & & Buffalo & 81 & 8 & 09.87 & 9 & 11.12 & 11 & 13.58 & \\
\hline & Total & & 567 & 48 & $\begin{array}{c}08.46 \\
(48 / 567)\end{array}$ & 53 & $\begin{array}{c}09.34 \\
(53 / 567)\end{array}$ & 64 & $\begin{array}{c}11.28 \\
(64 / 567)\end{array}$ & \\
\hline
\end{tabular}

In a present study the nonsignificant association between Brucella infection and risk factors such as abortion, metritis, retention of placenta, stillbirth and repeat breeding was reported. Some researchers report was similar to present findings Mugizi et al., (2015) and Asmare et al., (2013) found no significant association between seroprevalence of Brucella in respect of abortion and retention of placenta. Aulakh et al., 2008; Adesokan et al., 2013 found significant association between brucellosis and abortion and retention of placenta, but not between brucellosis and repeat breeding.

In conclusion, the higher prevalence of the disease in this region increases the risk of zoonotic transmission and it implies a serious threat to the human population as well as the huge impact on economy by losses in productivity of the livestock.Control of brucellosis in bovines through approved projection such as vaccinations either with S19 or RB51 reduces the likelihood of a transmission process from animal-animal. This strategy reduces the incidence of brucellosis, thus decreasing the spread into human populations. The higher prevalence of the disease over the population such as increases the risk of zoonotic transmission and it implies a serious threat to the human population as well as the huge impact on economy due to loss of productivity as well as loss of livestock population.

\section{Conflict of interests}

The authors declare that they have no conflict of interests with any financial organisation regarding the material discussed in the manuscript.

\section{Acknowledgement}

The authors are highly thankful to Indian Council of Agricultural Research, New Delhi and Dean, College of Veterinary Science and Animal Husbandry, Uttar Pradesh Pandit 
Deen Dayal Upadhayay Pashu Chikitsa Vigyan Vishvidhyalaya Ewam GoAnusandhan Sansthan (DUVASU), Mathura, U.P., India, for providing necessary funds and facilities to carry out the investigations.

\section{References}

Adesokan, H.K., Alabi, P.I., Stack, J.A., and Cadmus, S.I.B. 2013. Knowledge and practices related to bovine brucellosis transmission amongst livestock workers in Yewa, south-western Nigeria. Journal of South African Veterinary Association, 84(1): 121-125.

Aggad, H. and Boukra, L. 2006. Prevalence of bovine and human brucellosis in western Algeria: comparison of screening tests. Eastern Mediterranean Health Journal, 12: 119-24

Ahmed, A.M. 2009. Seroprevalence of cattle brucellosis in Gabiley District, Somaliland. Master's Thesis submitted to Sheikh Technical Veterinary School, Somaliland.

Alton, G.G., Jones, L.M., Angus, R.D. and Verger, J.M. 1988. Techniques for the Brucellosis Laboratory (2nd edn.), INRA, Paris, France.

Asmare, K., Sibhat, B., Molla, W.,Ayelet, G., Shiferaw, J., Martin, A.D., Skjerve, E., andGodfroid J. 2013. The status of bovine brucellosis in Ethiopia with special emphasis on exotic and cross bred cattle in dairy and breeding farms. ActaTropica, 126(3):186-192.

Aulakh, H.K., Patil, P.K., Sharma, S., Kumar, H., Mahajan, V., and Sandhu, K.S. 2008. A study on the epidemiology of bovine brucellosis in Punjab (India) using MilkELISA. Acta Veterinaria Brno, 77: 393 399

Berhe, G., Belihu, G. and Asfaw, A. 2007. Seroepidemiological Investigation of Bovine Brucellosis the Extensive Cattle Production System of Tigray Region of
Ethiopia. International Journal of applied research in Veterinary Medicine, 5: 26570.

Chand, P. and Chhabra, R. 2013. Herd and individual animal prevalence of bovine brucellosis with associated risk factors on dairy farms in haryana and Punjab in India. Tropical Animal Health Production, 45: 1313-1319.

Eshetu, Y., Kassahun, J., Abebe, P., Beyene, M., Zewdie, B., and Bekele, A. 2005. Seroprevalence study of brucellosis Trop Anim Health Prod on dairy cattle in Addis Ababa. Bulletin of Animal Health and Production for Africa, 53: 211-214.

Fichi, T.A. 2003. Intracellular survival of Brucella: defining the link with persistence. Veterinary Microbiology, 92: 213-223.

Geering, W.A., Forman, J.A., and Nunn, M.J. 1995. Exotic Diseases of Animals. Aust. Gov. Publishing Service, Canberra, Australia.

Kassahun, A. 2004.Epidemiology of Brucellosis in Cattle and Its Seroprevalence in Animal Health Professionals in Sidama Zone, Southern Ethiopia. Masters Thesis, FVM, AAU, DebreZeit, Ethiopia.

Hassan, M., Mai Peter, C., Kabir, I.J. and Peter, N.T. 2012. A large seroprevalence survey of brucellosis in cattle herds under diverse production systems in northern Nigeria, BMC Veterinary Research, 8: 144-147

Junaidu, A.U., Oboegbulem, S.I., and Salihu, M.D. 2011.Serological survey of Brucella antibodies in breeding herds. Journal of Microbiology and Biotechnology Research, 1: 60-65.

Kebede, T., Ejeta, G. and Ameni, G. 2008.Seroprevalence of bovine brucellosis in small holder farms in central Ethiopia (Wuchale-Jida district). Revue Méecine Véterinaire, 159: 3-9

Kollannur, J.D., Rathore, R., and Chauhan, 
R.S. 2007. Epidemiology and Economics of Brucellosis in Animals and its Zoonotic Significance. ISAH, Tartu, Estonia. Pp. 466-468.

Manish, K., Chand, P., Rajesh, C., Teena, R. and Sunil, K. 2013. Brucellosis: An updated review of the disease. Indian Journal of Animal Sciences, 83: 3-16

Mantur, B.G., Amarnath, S.K., Parande, A.M., Patil, G.A., Walvekar, R.R., Desai, A.S., Parande, M.V., Shinde, R.S., Chandrashekar, M.R. Patil, S.D., Shivaram, C., Salagare, R.C. 2011. Comparison of a novel immunocapture assay with standard serological methods in the diagnosis of Brucellosis. Clinical Laboratory, 57(5-6): 333-341.

Matope, G., Bhebhe, E., Muma, J.B., Oloya, J., Madekurozwa, R.L., Lund, A., Skjerve, E. 2011. "Seroprevalence of brucellosis and its associated risk factors in cattle from small holder dairy farms in Zimbabwe. Tropical Animal Health Production,43: 975-982

Mugizi, D. 2015. Relationship between bovine brucellosis and production systems in Kashongi sub-county of Kiruhura-Uganda. Bulletin of Animal Health and Production for Africa, 57(3): 209-219.

Neha, Ahmed, W., Verma, A.K., Jain, U.
andBist, B.2014. Brucellosis in organised dairy form: an investigation. Asian Journal of Animal Science, 8(1): 29-33.

OIE, 2011. Bovine brucellosis: In Manual of Diagnostic Tests and Vaccines for Terrestrial Animals. World Organization for Animal Health, Paris, France. Pp. 135.

Radostits, O.M., Gay, C.C., Blood, D.C., and Hinchliff, K.W. 2000. Veterinary medicine: a text book of diseases of cattle, sheep, pigs, goats and horses. 9th edition, Pp. 867-881.

Refai, M. 2002. Incidence and control of brucellosis in the Near East region. Veterinary Microbiology, 90: 81-110.

Renukaradhya G.J., Isloor S. and Rajasekhar M. 2002.Epidemiology, zoonotic aspects, vaccination and control/eradication of brucellosis in India. Veterinary Microbiology, 90: (1-4), 183-195.

Sehgal, S. and Bhatia, R. 1990.Zoonosis in India. Journal of Communicable Disease, 22: 227-235

Sundar, A., Sinha, D.K., and Singh, D.K. 2015. Comparative Study on Seroprevalence of Bovine Brucellosis by Serological Tests and Serum based PCR. Journal of Veterinary Public health, 13 (1): $9-13$.

\section{How to cite this article:}

Raghavendra Prasad Mishra, Udit Jain, Kaushal Kusum, Parul Singh, Barkha Sharma and Gourab Basak. 2020. Brucellosis and Associated Risk Factors Analysis in Serum Sample of Bovines. Int.J.Curr.Microbiol.App.Sci. 9(07): 1977-1983.

doi: https://doi.org/10.20546/ijcmas.2020.907.226 